\title{
Light interception, chemical, and productive characteristics of elephant grass subjected to different cutting intervals
}

\section{Interceptação luminosa, características químicas e produtivas do capim-elefante submetido a diferentes intervalos de corte}

\author{
Sâmara Stainy Cardoso Sânches ${ }^{1}$; Rosane Cláudia Rodrigues ${ }^{1}$; Ricardo Alves \\ de Araújo $^{1 *}$; Clésio dos Santos Costa ${ }^{2}$; Franscisco Naysson de Sousa Santos ${ }^{3}$; \\ Francisco Martins de Castro ${ }^{4}$; Francirose Shigaki ${ }^{5}$; Ivo Guilherme Ribeiro de \\ Araújo $^{1}$; Ivone Rodrigues da Silva ${ }^{6}$; Jocélio dos Santos Araújo ${ }^{1}$
}

\begin{abstract}
This study aimed to evaluate the interception of light (\%IL), leaf area index (LAI), and the chemical and productive characteristics of elephant grass (Pennisetum purpureum Schum) under different defoliation frequencies $(30,45,60,75$, and 90 days after cutting). The experimental design was completely randomized with five replications and five treatments (cutting frequencies). The chemical composition was analyzed in a factorial arrangement $2 \times 5$ (two fractions: leaf and stem, and five defoliation frequencies). The pattern of variation in IL and LAI in function of the frequency of cutting was ascending order. The maximum values of \% IL and LAI occurred at 75 and 90 days after cutting with $98.46 \% ; 98.72 \%(\% \mathrm{IL})$ and $7.08 ; 8.10(\mathrm{LAI})$, respectively. There was no effect of cutting frequency on the total yield of forage, leaf production, generation of stem and dead material, tillers alive, dead tillers and height. Only the leaf/stem ratio was not influenced $(\mathrm{P}>0.05)$ among the factors studied. The frequency of cutting influenced $(\mathrm{P}<0.05)$ the chemical composition, where decreased cutting frequency significantly increased the levels of dry matter, neutral detergent fiber, acid detergent fiber, cellulose, and ash in two fractions evaluated (leaf and stem); the crude protein content showed a decline from the moment the frequency of cutting was increased. The LAI, and productive and chemical characteristics of elephant grass were influenced by increased frequency of cutting. Limiting the cutting of the grass to 60 days implies an optimal point of production and quality.
\end{abstract}

Key words: Crude protein. Forage production. Leaf area index. Leaf production.

1 Zootecnistas, Profs., Universidade Federal do Maranhão, UFMA, Departamento de Zootecnia, Chapadinha, MA. Brasil. E-mail: samara-sanches12@hotmail.com; rosanerodrig@gmail.com; ricardo_zoo@hotmail.com; igravet@hotmail.com; jocelios@ yahoo.com.br

2 Zootecnista, Discente de Doutorado, Programa de Doutorado Integrado em Zootecnia, Universidade Federal do Ceará, UFC, Departamento de Zootecnia, Fortaleza, CE. Brasil. E-mail: clesiosantzoo@gmail.com

3 Zootecnista, Discente de Doutorado, Programa de Doutorado Integrado em Zootecnia, Universidade Federal da Paraíba, UFPB, Departamento de Zootecnia, Areia, PB. Brasil. E-mail: nayssonzootecnista@gmail.com

4 Zootecnista, Docente, Escola Superior do Amazonas, ESBAM, Departamento de Medicina Veterinária, Manaus, AM. Brasil. E-mail: fcastrozoot@hotmail.com

5 Zootecnista, Prof ., UFMA, Departamento de Biologia, Chapadinha, MA. Brasil. E-mail: francirose@yahoo.com.br

6 Zootecnista, Discente de Doutorado, Programa de Pós-Graduação em Ciência Animal, Universidade Federal do Piauí, UFPI, Departamento de Zootecnia, Teresina, PI. Brasil. E-mail: ivonerodrigues10@hotmail.com

* Author for correspondence 


\title{
Resumo
}

\begin{abstract}
Objetivou-se avaliar a interceptação luminosa (\%IL), índice de área foliar (IAF), as características produtivas e químicas do capim-elefante (Pennisetum purpureum Schum) sob diferentes frequências de corte (30, 45, 60, 75 e 90 dias após o corte). Utilizou-se o delineamento inteiramente casualizado, com cinco repetições e cinco tratamentos (frequências de corte). A composição química foi analisada em arranjo fatorial $2 \times 5$ (duas frações: folha e colmo e cinco frequências de corte). $O$ padrão de variação da IL e IAF em função das frequências de corte foi de ordem crescente. Os máximos valores de IL e IAF ocorreram aos 75 e 90 dias de corte com 98,46\%; 98,72\% (\%IL) e 7,08; 8,10 (IAF), respectivamente. Houve efeito das frequências de corte para a produção total de forragem, produção de folhas, produção de colmo, material morto, perfilhos vivos, perfilhos mortos e altura. Apenas a relação folha/colmo não foi influenciada $(\mathrm{P}>0,05)$ pelos fatores estudados. As frequências de corte influenciaram $(\mathrm{P}<0,05)$ a composição química, onde a diminuição da frequência aumentou significativamente os teores de matéria seca, fibra em detergente neutro, fibra em detergente ácido, celulose e cinzas nas duas frações avaliadas (folha e colmo), já o teor de proteína bruta apresentou queda a partir do momento que aumentou as frequências de corte. O Índice de área foliar, as características produtivas e químicas do capim-elefante são influenciadas pelo aumento na frequência de corte. O corte do capim aos 60 dias implica em um ponto ótimo de produção e qualidade.
\end{abstract}

Palavras-chave: Proteína bruta. Produção de forragem. Índice de área foliar. Produção de folha.

\section{Introduction}

The elephant grass (Pennisetum purpureum Schum) is a poácea originating in Africa, and is one of the most important seeds used in tropical regions, being cultivated in almost all tropical and subtropical regions of the world due to its high potential of production of dry mass, nutritive value, force and persistence (PEREIRA et al., 2010). In spite of research related to the morphological characterization of this forage plant being already well-disseminated, including regarding its nutritional value, there are still certain difficulties involving its management, mainly in the definition of the ideal period for harvesting.

Elephant grass has the ability to easily adapt to various ecosystems, an important characteristic of which is acceptance by animals. This poácea offers the possibility of being used in different ways, among which are the grazing and fodder preserved (silage or hay). The management of cutting the harvest is a factor that modifies both the production and the quality of the forage. More frequent cutting results in lower dry matter production, with, however, greater nutritional value for cutting performed less frequently, which provides higher dry matter production, but of lesser quality (VERAS et al., 2010). Therefore, correlation of the harvest interval with light interception may define a method of more efficient management of this forage crop. In this sense, factors that interfere with the quality of forage grasses can involve anatomic origin, physics, and chemistry, in addition to those related to the structure of the vegetation, which are directly related to the management of pastures (SANCHÊS et al., 2018).

It should be emphasized, however, that fixed values of leaf area index (LAI) should not be used as the sole form of management for determining the ideal interval, since this is likely to vary between species or even between different genotypes of the same species, and may also suffer from the influence of environmental factors, crop management, and the grazing method used (CARVALHO et al., 2007). In this sense, the objective of this work was to evaluate the light interception (\%IL), and chemical and productive characteristics of elephant grass subjected to different frequencies of cutting. 


\section{Material and Methods}

The experiment was carried out at the Forage Crops Section at CCAA/UFMA (034ㄴ $33^{\prime \prime}$ $\left.\mathrm{S}, 43^{\circ} 21^{\prime} 21^{\prime \prime} \mathrm{W}\right)$. According to the Köppen classification, the climate in the region is a hot wet tropical type (Aw) with average annual temperature higher than $27{ }^{\circ} \mathrm{C}$ and average annual precipitation of $1,835 \mathrm{~mm}$, rainy periods between January and June, and dry periods from July to December (Maranhão 2002). Precipitation and temperature data recorded during the experimental period are described in Figure 1.

Figure 1. Average rainfall during the completion of the experiment.

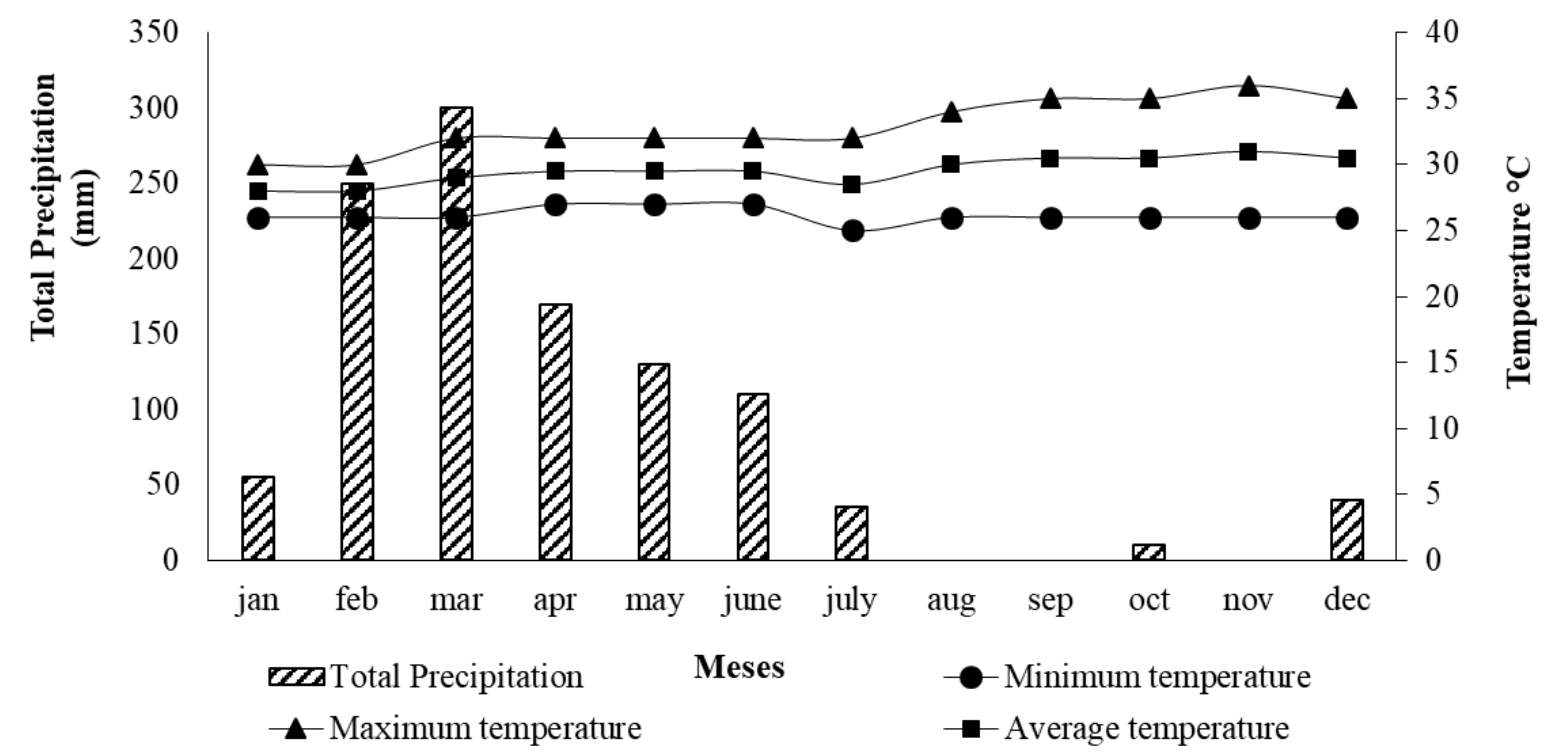

Source: INMET, 2015.

The soil of the experimental site was classified as yellow latosol (SANTOS et al., 2013). Presenting the following chemical characteristics: $\mathrm{pH}$ in $\mathrm{CaCl}_{2}$ $19 \mathrm{~g} / \mathrm{dm}^{3} ; \mathrm{P}=5$ and $\mathrm{S}=9 \mathrm{mg} / \mathrm{dm}^{3}$, respectively; $\mathrm{K}=0.4, \mathrm{Ca}=5, \mathrm{Mg}=2, \mathrm{H}+\mathrm{Al}=29, \mathrm{Al}=8, \mathrm{CTC}$ $=36, \mathrm{SB}=7.4 \mathrm{mmolc} / \mathrm{dm}^{3}$, respectively; $\mathrm{V}=20$ and $\mathrm{m}=52 \%$; and $\mathrm{b}=1.43, \mathrm{Cu}=0.2=55, \mathrm{Fe}, \mathrm{Mn}$ and $\mathrm{Zn}=0.4=0.3 \mathrm{mg} / \mathrm{dm}^{3}$, respectively. The liming was performed by the method of lifting the base saturation (V\%), raising V\% of 20 to $60 \%$.

The total field area used in the experiment was $784 \mathrm{~m}^{2}$, being subdivided into 25 plots of $31.36 \mathrm{~m}^{2}$ each (experimental units). The forage species used was the elephant grass (Pennisetum purpureum Schum.), which was divided into different defoliation frequencies $(30,45,60,75$, and 90 days), these being the treatments. The experimental design was completely randomized with five replicates. The chemical-bromatological composition was in a $2 \times 5$ factorial arrangement (two fractions: leaf and stem, and five defoliation frequencies). The experiment was carried out using pasture already pre-established, implemented in June/August 2013, by means of seedlings with row spacing of $50 \mathrm{~cm}$.

Fertilization was done in accordance with indications from the analysis of the soil and was equal for all treatments, with a high technological level. The cut of standardization was performed on 05 February 2015, when soon after, fertilization was performed by coverage with $\mathrm{N}\left(300 \mathrm{~kg} \mathrm{ha}^{-1}\right), \mathrm{K}_{2} \mathrm{O}$ $\left(60 \mathrm{~kg} \mathrm{ha}^{-1}\right)$ and $\mathrm{P}_{2} \mathrm{O}_{5}\left(90 \mathrm{~kg} \mathrm{ha}^{-1}\right)$. The nitrogen was administered in a single dose, except for fertilization that was divided across two events. 
After the cutting of standardization, the plots were cut in accordance with the frequencies of preestablished cutoffs (30, 45, 60, 75, and 90 days), on the day of completion of cutting, evaluation was conducted by the monitoring of light interception by the canopy, using the analyzer - AccuPAR Linear PAR/LAI ceptometer, Model PAR-80 (DECAGON Devices). Readings were performed at four sampling points per plot, taking in each location one reading above and one below the canopy, using a reference height of $25 \mathrm{~cm}$ (SANCHÊS et al., 2018).

The heights of the experimental units were measured using a ruler $5 \mathrm{~m}$ length and graduated in centimeters. Readings were taken at five random points per experimental unit. The readings from the heights were always performed before cutting, taking as a reference the curvature of the leaf.

For the determination of productive characteristics, two samples representative of the experimental plots were collected before cutting, using PVC frames of $0.25 \mathrm{~m}^{2}$. The frames were positioned at points representing the average height of the pastures at the time of sampling, and the plants contained within each frame were cut according to the height of the residue $(25 \mathrm{~cm})$. The material was fractionated into leaf blade, stem + sheath, and dead material for the determination of the percentage of morphological components.

After separation, the material was weighed on an analytical balance and placed in a forced ventilation oven at $65^{\circ} \mathrm{C}$ for 72 hours, then weighed and milled with $1 \mathrm{~mm}$ sieves in a Willey-type mill, and packed and sealed in plastic bags. Determination of levels of dry matter (method no 934.01), organic matter (method no 942.05), and crude protein (paragraph 954.01), were done according to the AOAC (2003). For the analysis of neutral detergent fiber (NDF) content, samples were treated with thermostable alpha-amylase, without the use of sodium sulfite, and corrected for residual ash (MERTENS, 2002).

The data were submitted to tests of normality and homoscedasticity before being performed the analysis of variance. The vaiáveis regarding the structure of pasture were compared by Duncan test at $5 \%$ probability by the PROC GLM procedure of SAS $^{\circledR}$ statistical program (Edition University, SAS Institute Inc., Cary, NC, USA), using the following statistical model:

\section{Model 1: $\mathrm{Y}_{\mathrm{ik}}=\mu+\mathrm{FD}_{\mathrm{i}}+\varepsilon_{\mathrm{ik}}$,}

Where Yik This is the dependent variable of the experiment measured at experimental unit " $\mathrm{k}$ " Cutoff frequency "i"; $\mu$ it is the constant general ; $\mathrm{FD}_{\mathrm{i}}$ It is the effect of the cutoff frequency “i”; e $\varepsilon_{\mathrm{ijk}}$ It is the effect of random error .

The variables concerning the chemical composition of pasture were compared by Duncan test at $5 \%$ probability by the PROC GLM procedure of SAS ${ }^{\circledR}$ statistical program (Edition University, SAS Institute Inc., Cary, NC, USA), using the following statistical model:

Model 2: $\mathrm{Y}_{\mathrm{ijk}}=\mu+\mathrm{FD}_{\mathrm{i}}+\mathrm{FP}_{\mathrm{j}}+\left(\mathrm{FD} \mathrm{x} \mathrm{FP}_{\mathrm{ij}}\right)+\varepsilon_{\mathrm{ijk}}$,

Where Yijk This is the dependent variable of the experiment measured at experimental unit " $k$ " Cutoff frequency " $i$ " And the fraction of the plant " $\mathrm{j}$ "; $\mu$ it is the constant general ; $\mathrm{FD}_{\mathrm{i}}$ It is the effect of the cutoff frequency " $\mathrm{i}$ "; $\mathrm{FP}_{\mathrm{j}}$ It is the effect of the plant fractions, leaf blade and stem " $\mathrm{j}$ "; FD x $\mathrm{FP}_{\mathrm{ij}}$ Is the effect of the interaction between cutoff frequency "i $i$ " And the fraction of the plant “ $\mathrm{j}$ "; e $\varepsilon_{\mathrm{ijk}}$ It is the effect of random error .

\section{Results and Discussion}

The pattern of variation of $\%$ IL in terms of the cutoff frequency was in increasing order (Figure 2), with increases of 0.1632 and 0.027 percentage points in \%IL and LAI per day, respectively. It is interesting to note that according to Chaves (2011), with increased \% IL, simultaneous increases in incremental forage production occur, until reaching a plateau, when the older leaves become senescent and are shaded by younger ones, resulting in reduced photosynthetic efficiency and lower rates of growth with the \% IL at around $95 \%$, behavior also observed in this study. 
Figure 2. Light Interception (\%LI) and leaf area index (LAI) in function of the different defoliation frequencies of elephant grass.

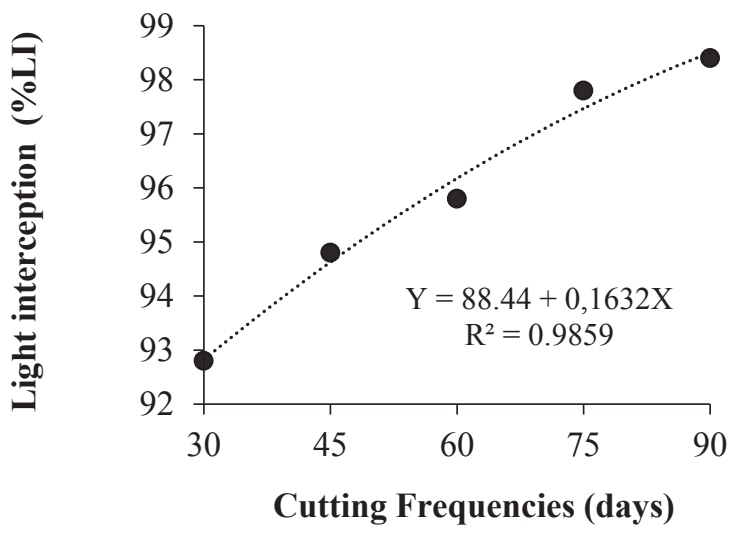

In this sense, the use of management strategies affects the characteristics of forage plants and the use of light interception as a reference for monitoring the process of regrowth, allowing the forage to be harvested by cutting or grazing, and always in the same physiological condition (PEDREIRA et al., 2007). In this way, the choice of a cutoff frequency combined with the use of \% IL, become viable alternatives for use as a way to optimize the productivity of animal production systems.

Viana et al. (2009), who evaluated clones of elephant grass grazed under intermittent animal stocking, with rest periods of 32 and 64 days, observed values of 86.5 and $91.2 \%$ IL, which are close to those found in this experiment of $92.88 \%$ (30 days) and $96.22 \%$ (60 days), respectively. The high values we observed may have been influenced by favorable climatic conditions during the experimental period, in addition to the use of

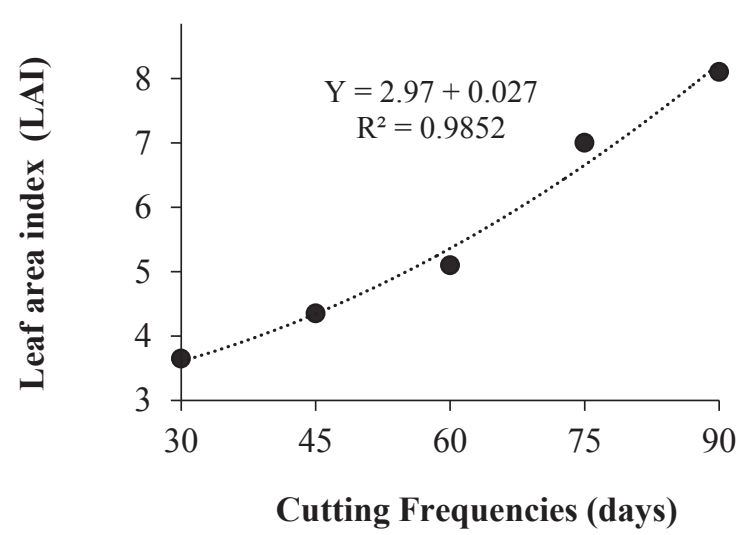

nitrogen fertilization administered at a single time, influencing rapid vegetative regrowth of harvested forage.

In relation to LAI, there was an increase in function with decreased defoliation frequency (Figure 2). A frequency of 90 days provided the highest values of LAI, with an average of 8.10; an increase of $5.96 \%$ from 30 to 90 days. The mean values of LAI exhibited strong influence from mineral fertilization and climatic conditions throughout the evaluation period. This behavior was due to the characteristics of forage plants and resulted in increases in the average height of the plants and in the number of tillers alive throughout the experimental period (Table 1), since the increase in the number of tillers contributed to elevated LAI (Figure 2) and, consequently, for greater \% $\mathrm{IL}$, especially with decreased defoliation frequency (Figure 2). 
Table 1. Total forage production (TFP), leaf production (LP), stem of production (SP), dead material (DM), leaf/stem ratio ( L/S), tillers alive (TA), dead tillers (DT) and height $(\mathrm{H})$ of elephant grass in different cutting frequencies.

\begin{tabular}{lcccccc}
\hline \multirow{2}{*}{ Characteristic } & \multicolumn{5}{c}{ Cutting frequencies (days) } & \multirow{2}{*}{ CV (\%) ${ }^{1}$} \\
\cline { 2 - 6 } & 30 & 45 & 60 & 75 & 90 & \\
\hline TFP $\left(\mathrm{kg}^{-1}\right.$ ha $^{-1}$ year $\left.^{-1}\right)$ & $25.802 .40 \mathrm{c}$ & $28.008 .80 \mathrm{c}$ & $30.294 .40 \mathrm{c}$ & $37.788 .00 \mathrm{~b}$ & $46.238 .40 \mathrm{a}$ & 13.43 \\
$\mathrm{LP} \mathrm{kg}^{-1} \mathrm{ha}^{-1}$ year $\left.^{-1}\right)$ & $9.485 .6 \mathrm{~b}$ & $10.351 .2 \mathrm{~b}$ & $10.533 .00 \mathrm{~b}$ & $13.428 .00 \mathrm{a}$ & $14.581 .60 \mathrm{a}$ & 11.51 \\
$\mathrm{PS} \mathrm{kg}^{-1} \mathrm{ha}^{-1}$ year $\left.^{-1}\right)$ & $16.262 .4 \mathrm{c}$ & $17.508 .00 \mathrm{c}$ & $18.356 .8 \mathrm{c}$ & $22.737 .2 \mathrm{~b}$ & $28.736 .8 \mathrm{a}$ & 13.24 \\
$\mathrm{DM} \mathrm{kg}{ }^{-1} \mathrm{ha}^{-1}$ year $\left.^{-1}\right)$ & $596.0 \mathrm{~b}$ & $916.0 \mathrm{ab}$ & $992.0 \mathrm{ab}$ & $1100.0 \mathrm{a}$ & $1130.0 \mathrm{a}$ & 34.39 \\
$\mathrm{~L} / \mathrm{S}$ & $0.60 \mathrm{a}$ & $0.59 \mathrm{a}$ & $0.64 \mathrm{a}$ & $0.64 \mathrm{a}$ & $0.51 \mathrm{a}$ & 16.86 \\
$\mathrm{TA}$ & $28.20 \mathrm{a}$ & $22.30 \mathrm{~b}$ & $20.40 \mathrm{~b}$ & $20.40 \mathrm{~b}$ & $20.20 \mathrm{~b}$ & 23.86 \\
$\mathrm{DT}$ & $6.20 \mathrm{bc}$ & $7.10 \mathrm{abc}$ & $4.70 \mathrm{c}$ & $8.10 \mathrm{ab}$ & $9.10 \mathrm{a}$ & 37.19 \\
$\mathrm{H}$ (meter) & $0.89 \mathrm{e}$ & $1.57 \mathrm{~d}$ & $2.12 \mathrm{c}$ & $2.42 \mathrm{~b}$ & $2.90 \mathrm{a}$ & 10.58 \\
\hline
\end{tabular}

Medium followed by lowercase equal in the lines did not differ $(\mathrm{P}<0.05)$ by Duncan's test . ${ }^{1}$ Coefficient of variation.

However, at a given moment, when plants begin to be limited in terms of light availability and quality of light inside the canopy, tillering is reduced by the death of tillers. Under such conditions, the increase in LAI which follows is due basically to increased size of existing tillers (height), data which can be observed in Table 1.

There was a significant effect $(\mathrm{P}<0.05)$ for the total forage production (TFP) of elephant grass as a function of the harvest frequency (Table 1), with maximum yield of $46,238.40 \mathrm{~kg} \mathrm{~kg}^{-1}$ ha- 1 year ${ }^{-1}$ for 90 days, followed by 75 days $\left(37,788.00 \mathrm{~kg}^{-1}\right.$ $\mathrm{ha}^{-1}$ year $\left.^{-1}\right)$; there was no significant difference $(\mathrm{P}$ $>0.05$ ) for the frequencies of 30,45 and 60 days, being that they presented lower TFP. This fact can be explained by the lower production of stalks and leafs checked for these frequencies, since plants in the initial stages of development present with low content of dry matter (DM), increasing with age.

In a study carried out by Magalhães et al. (2009) with the elephant grass cv. Napier subjected to different doses of $\mathrm{N}\left(150 ; 300\right.$ and $\left.450 \mathrm{~kg} \mathrm{~N} \mathrm{ha}^{-1}\right)$ and five increments of cuts $(28 ; 35 ; 42 ; 56$ and 84 days), these authors verified an increase in production of DM when the cutoff frequency increased from 28 to 84 days, these values being influenced by an increase in the production of stalks, behavior similar to that observed in the present study.
In relation to leaf production (LP) there was no significant difference in the cutting frequencies of 75 and 90 days, which also had the highest yields. In a study carried out by Flores et al. (2012) with the cv. Paradise subjected to different doses of $\mathrm{N}$ $\left(0,50,100\right.$ and $\left.150 \mathrm{~kg} \mathrm{ha}^{-1}\right)$ and three ages of cuts (120, 150 and 180 days after budding), there was an increase in LP and stem production (SP) when the defoliation frequency increased from 120 to 180 days, an increase of 35.31 and $19.59 \%$, respectively. Values close to those that were found in the present study, with an increase in LP of $34.95 \%$, with SPincreased in the order of $43.40 \%$, from 30 to 90 days, respectively. Considering that the highest values of crude protein and digestibility are found in the leaves, cut grass for use in animal feed above the 90 days of regrowth should result in a drop in quality, due to increased stem fraction in the fodder produced.

Analyzing the data of leaf/stem ratios, there was no significant difference in the different defoliation frequencies evaluated (Table 1). Work carried out by Italiano et al. (2006) to evaluate the productive behavior of genotypes of elephant grass fertilized with $200 \mathrm{~kg}$ of $\mathrm{N}$, the authors obtained an average proportion of $0.70 \mathrm{~L} / \mathrm{S}$ in relation to the genotypes evaluated at 90 days of age. The higher values obtained in this study, where the frequency of cutting 
was 90 days, the elephant grass showed a leaf/ stem ratio of 0.51 . The low values of the $\mathrm{L} / \mathrm{S}$ ratio in all treatments probably resulted from a higher percentage of stalks, with further development of the plants and the elongation of stems more pronounced.

According to Costa et al. (2017) low frequencies of cutting provide high leaf/stem ratios, which gives the grass better adaptation to grazing or tolerance to cutting, because it represents a moment of phenological development in which the apical meristems are closer to the ground and therefore less vulnerable to destruction.

The largest number of tillers alive (TA) were observed with a cutting frequency of 30 days, the others did not differ from these expected values, since higher cutoff frequencies provided greater development of vegetative tillers due to the high incidence of light in axillary buds of plants that induce the tillering. Decrease in the cutoff frequency resulted in greater plant development, and consequently in the elongation of stems that prevent the entry of light into the basal part of the plant, which limits the development of these tillers.

As for the variable dead tillers (DT), the behavior was different, being that the 90 days interval showed the highest number of dead tillers, followed by treatments of 75 and 45 days to 60 days, which resulted in lower observed values. This variable is very unstable, and very much depends on the climatic conditions, entry of light in the basal part of the plant, and management of grass, however, cutting intervals extended influence in the increase of the number of dead tillers.
This emphasizes that the increase in the number of DTs was probably influenced by the high LAI (Figure 2), which promotes a reduction in the quantity and quality of light that reaches the axillary buds, thus hindering tillering. In this way, Cutrim Junior et al. (2014) reported that these factors are intertwined with the reduction in the speed of growth of pasture with advancing age due to the intensification of shading, triggering leaf senescence, reducing the photosynthetic efficiency of the leaves and increasing respiratory losses of the plant.

Plant height was influenced significantly $(\mathrm{P}<$ $0.05)$ by the interval between cuts, ranging from $0.89 \mathrm{~m}$ (30 days) to $2.90 \mathrm{~m}$ (90 days), an increase of $69.32 \%$. The high values observed are due to the high development of vegetative tillers, associated with the application in a single dose of nitrogen fertilization, resulting in rapid development.

We observed an effect $(\mathrm{P}<0.05)$ between the fractions within the frequencies applied (Table 2). The cutoff frequency influenced the contents of DM only on the leaf fraction, being that these values tended to increase with the decrease of the cutoff frequencies studied, which on average, ranged from $15.53 \%$ (30 days) to $20.73 \%$ (90 days).

It is known that the biggest changes that occur in the chemical composition of forage plants are those that accompany their maturation, in this way, the plant, when new, presents high levels of water and that content is reduced when the plant is approaching maturity, so that the content of DM gradually increases. Costa et al. (2007) also observed an increase in dry matter with advancing age of the plant; these values ranged between 16 and $26 \%$ analyzed between 15 and 60 days of growth of Urochoa brizantha cv. MG-5. 
Table 2. Average levels of dry matter (DM), crude protein (CP), neutral detergent fiber (NDF), and acid detergent fiber (ADF) of leaf and stem fractions of elephant grass in different cutting frequencies.

\begin{tabular}{|c|c|c|c|c|c|c|c|c|}
\hline \multirow{3}{*}{$\begin{array}{l}\text { Fraction } \\
\text { (F) }\end{array}$} & \multicolumn{5}{|c|}{ Cutting frequencies (CF; days) } & \multirow{3}{*}{ Mean } & \multirow{3}{*}{$\mathrm{F} \mathrm{X} \mathrm{CF}{ }^{1}$} & \multirow{3}{*}{$\mathrm{CV}(\%)^{2}$} \\
\hline & 30 & 45 & 60 & 75 & 90 & & & \\
\hline & \multicolumn{5}{|c|}{ DM (\%) } & & & \\
\hline Leaf & $15.53 \mathrm{Ad}$ & $17.57 \mathrm{Ac}$ & $18.87 \mathrm{Ab}$ & 19.82Bab & $20.73 \mathrm{Ba}$ & 18.50 & & \\
\hline Stem & $16.55 \mathrm{Ac}$ & 17.19Ac & $20.44 \mathrm{Ab}$ & $22.04 \mathrm{Aab}$ & 23.33Aa & 19.90 & 0.0318 & 5.58 \\
\hline \multirow[t]{2}{*}{ Mean } & 16.04 & 17.38 & 19.65 & 20.93 & 22.02 & & & \\
\hline & \multicolumn{5}{|c|}{$\mathrm{CP}(\%)$} & & & \\
\hline Leaf & $19.88 \mathrm{Aa}$ & $18.39 \mathrm{Ab}$ & $13.26 \mathrm{Ac}$ & $12.87 \mathrm{Ac}$ & $11.96 \mathrm{Ac}$ & 15.27 & & \\
\hline Stem & $12.94 \mathrm{Ba}$ & $11.55 \mathrm{Bb}$ & $11.05 \mathrm{Bb}$ & $10.95 \mathrm{Bb}$ & $9.45 \mathrm{Bc}$ & 11.18 & $<0.0001$ & 6.7 \\
\hline \multirow[t]{2}{*}{ Mean } & 16.41 & 14.96 & 12.15 & 11.91 & 10.7 & & & \\
\hline & \multicolumn{5}{|c|}{ NDF (\%) } & & & \\
\hline Leaf & 66.16Ae & $70.54 \mathrm{Bd}$ & $72.82 \mathrm{Bc}$ & $75.75 \mathrm{Bb}$ & $79.57 \mathrm{Ba}$ & 72.96 & & \\
\hline Stem & $67.35 \mathrm{Ae}$ & 73.26Ad & 76.24Ac & $80.66 \mathrm{Ab}$ & $84.28 \mathrm{Aa}$ & 76.35 & 0.019 & 1.77 \\
\hline \multirow[t]{2}{*}{ Mean } & 66.75 & 71.89 & 74.52 & 78.2 & 81.92 & & & \\
\hline & \multicolumn{5}{|c|}{ ADF (\%) } & & & \\
\hline Leaf & $44.57 \mathrm{Be}$ & $49.17 \mathrm{Bd}$ & $52.65 \mathrm{Bc}$ & $55.59 \mathrm{Bb}$ & $58.46 \mathrm{Ba}$ & 52.08 & & \\
\hline Stem & $52.02 \mathrm{Ae}$ & $57.76 \mathrm{Ad}$ & 65.06Ac & $69.23 \mathrm{Ab}$ & 75.54Aa & 63.92 & $<0.0001$ & 2.48 \\
\hline Mean & 48.29 & 53.46 & 58.85 & 62.41 & 66.99 & & & \\
\hline
\end{tabular}

Medium followed by equal letters uppercase and lowercase letters columns in the lines did not differ $(\mathrm{P}<0.05)$ by Duncan test. ${ }^{1}$ Effect of interaction ${ }^{2}$ Coefficient of variation.

The frequency of cut influenced $(\mathrm{P}<0.05)$ the levels of leaf protein and stem fractions (Table 2). These contents did not defer between the lowest and highest defoliation frequencies; however, there was a sharp fall over the days of evaluation. These results were expected, since, as the plant matures, there is a decrease in cellular content and, consequently, a decline in the percentage of crude protein (CP), as was observed in this study. The decrease in leaf fraction was $39.84 \%$ from 30 to 90 days, and for the stem fraction was $26.97 \%$ between 30 and 90 days, respectively. In a study carried out by Magalhães et al. (2009) with three elephant grass cultivars and five increments of cuts, it was observed that the levels of crude protein decreased significantly $(\mathrm{P}<$ 0.05 ) with the cutting age.

The highest content was recorded with 28 days (13.77\%) and the lowest with 84 days (4.75\%). These results are close to those found in this study.
Protein, followed by energy, is the most required nutrient by ruminants (RODRIGUES JÚNIOR et al., 2015). According to Carvalho et al. (2011), 7\% $\mathrm{CP}$ is the minimum content of this nutrient capable of providing adequate fermentation of fibrous carbohydrates in the rumen. In the present study, the two fractions met this limit, even at the lowest cutting frequency evaluated (90 days).

In two fractions (leaf and stem) of elephant grass evaluated, the NDF content responded $(\mathrm{P}<0.05)$ to the frequencies imposed, with the highest levels observed at 90 days, indicating a reduction in the quality of the forage with the advancing age of the plant, a fact also reported by Magalhães et al. (2009). Analyzing the fractions within the frequencies, there was no significant difference $(P>0.05)$ in the NDF content at a frequency of 30 days; this result is explained by the high incidence of new material and material still in development. 
Sanchês et al. (2018) observed that in plants of elephant grass, as the cells mature, the production of potentially digestible components tends to decrease, and the fiber content increases with advancing of the stage of maturation of the forage harvester, and natural senescence occurs, contributing to increased lignification.

In a study carried out by Flores et al. (2013), these authors reported values below those found in this study for the two fractions evaluated, where with the defoliation frequency of 180 days, the stem showed $66.3 \%$ and $56.9 \%$ NDF leaf, respectively. In this work, the values for these two fractions were close to $79.57 \%$ and $84.28 \%$, for leaf and stem, respectively. In accordance with Mistura et al. (2007), these high values occur due to edaphoclimatic favorable factors during the evaluation period of study and the greater availability of mineral nutrients in the soil solution, providing greater growth and development of elephant grass tillers.
The levels of acid detergent fiber (ADF) of the leaves and stems responded to the effects of defoliation frequencies $(\mathrm{P}<0.05)$, probably as a result of the increase in the proportion of constituents of the cell wall with lower defoliation frequency evaluated. The levels observed in this study were considered elevated if compared to values reported by Teixeira et al. (2015), Cruz et al. (2010) and Martins-Costa et al. (2008) 44.53\% (112 days); 45.5\% (60 days) and 47.81\% (105 days), respectively. According to Rodrigues Júnior et al. (2015), the levels of ADF are relation to the lignin content of foods, which determines its digestibility, because the lower the content of ADF, the less will be the content of lignin with, consequently, improved digestibility of food.

There was no effect $(\mathrm{P}>0.05)$ of the interaction of fraction $\times$ frequency of cuts on the levels of lignin (LIG) (Table 3), as for the other variables, there was no effect of the interaction $(\mathrm{P}<0.05)$.

Table 3. Average levels of lignin (LIG), cellulose (CEL), hemicellulose (HEM) and ash leaf and stem fractions of elephant grass in different cutting frequencies.

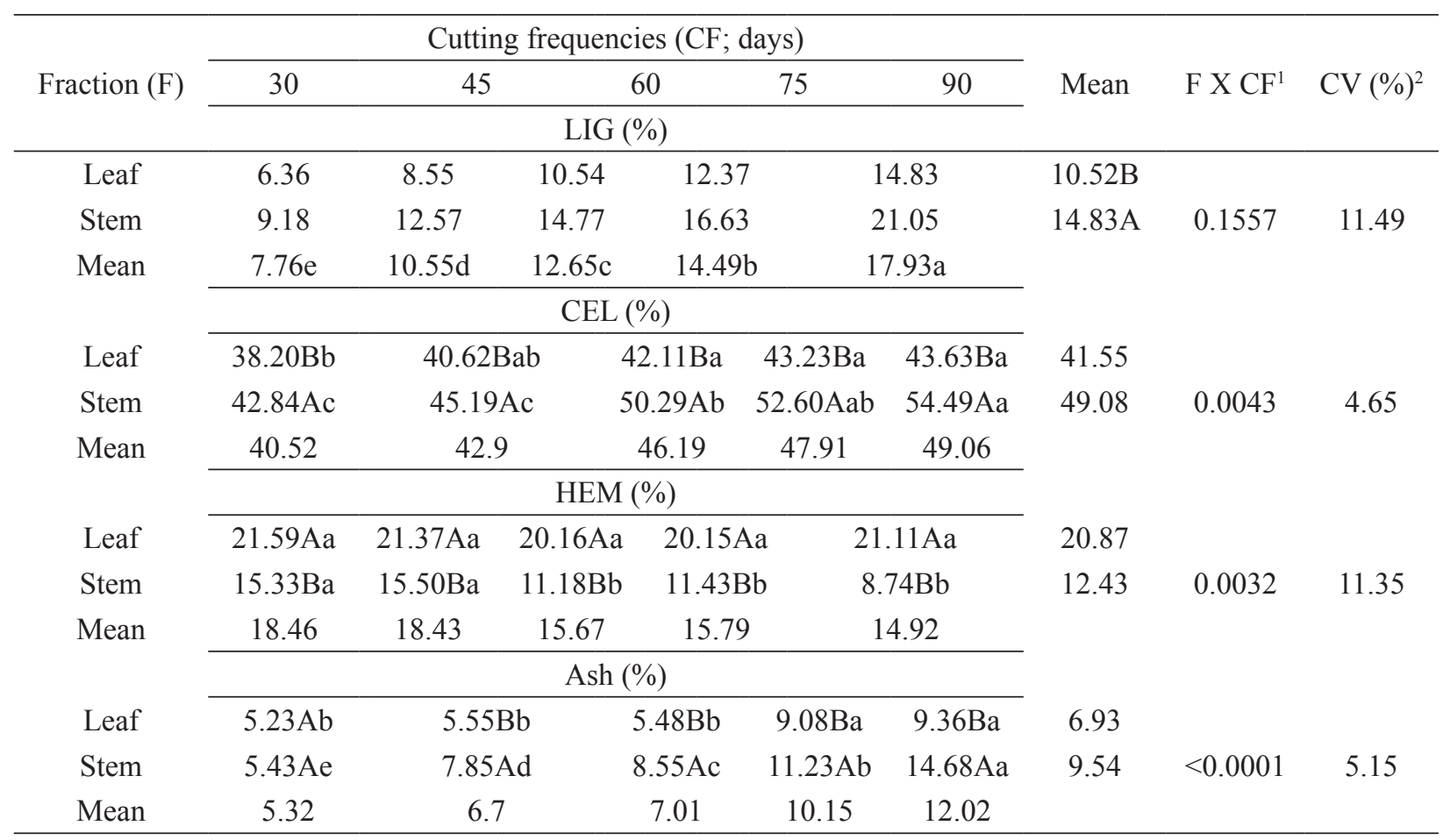

Medium followed by equal letters uppercase and lowercase letters columns in the lines did not differ $(\mathrm{P}<0.05)$ by Duncan test. ${ }^{1}$ Effect of interaction ${ }^{2}$ Coefficient of variation. 
Analyzing the mean levels of LIG in fractions, we observed higher values for stem $(14.83 \%)$, with a decrease in the frequency of cuts these levels tended to continuous growth of $56.72 \%$ (30 to 90 days). In this way, the arrangement in the structure of these cells promote the increase in material of the plant's resistance, reducing the nutritive value with increased cutting age. In this sense, the maturation of the plant entails an increase in this component, influencing the qualitative aspects of seed (SÂNCHES et al., 2018).

There were variations in the cellulose content between the cutting frequencies imposed on the plants. The stem showed the highest values in all frequencies evaluated. Analyzing the fractions within the frequencies, all the fractions presented an increase with the increase in the age of cut, in which, at 90 days of age, presented their maximum values of $43.63 \%$ (leaf) and $54.49 \%$ (stem), an increase of $12.44 \%$ and $22.02 \%$ (leaf and stem) from 30 to 90 days, respectively. In a study carried out by Teixeira et al. (2015) with elephant grass using three frequencies of cut $(56,84$ and 112 days) the observed levels of cellulose were $33.60 ; 39.17$ and $38.02 \%$, respectively, an increase of $11.62 \%$ (from 56 to 112 days), values below those reported in this study. The high values of cellulose found in this study were influenced mainly by the high mineral fertilization administered at a single time, which resulted in the rapid development of this forage harvest, in addition to the edaphoclimatic conditions that were favorable to the development of the plant at the time of evaluation (a rainy period).

By analyzing the contents of the hemicellulose fractions within the defoliation frequencies, it was observed that there was a significant difference $(\mathrm{P}<$ $0.05)$, being that the leaf presented larger proportions than expected values, considering that the leaves are composed of lower levels of ADF and LIG in relation to the stem; these variables affect the nutritive value of grasses. In this sense, the hemicellulose (a fraction with a higher percentage on the sheet) undergoes rapid utilization by ruminal microbiota.
Determination of the levels of ash provided an indication of the concentrations of mineral nutrients from grass. In this experiment, the levels of ash in the leaves and culms showed significant effect $(\mathrm{P}<$ 0.05 ), with a decrease in frequencies. At the same time, analyzing the effect of the fractions within the frequencies, there was no difference for 30 days. Sanchês et al. (2019), observed that, with maturation of the plants of elephant grass there is, commonly, a drop in the levels of minerals, due to the effect of their dilution in the dry matter produced, which is directly related to changes in plant tissues. There was also a reduction in leaf/stem ratio, increase in senescent leaves, diversity in the pattern of absorption of elements during the cycle of the plants, and redistribution among the various organs of plants, leading to the decrease of the concentration of minerals in the plant (RODRIGUES JÚNIOR et al., 2015).

Flores et al. (2013) showed reductions in levels of ash of elephant grass, as a function of the age increase utilization, decrease of $12.28 \%$ (stem) and $14.42 \%$ (leaf) of 120 to 180 days, however, these values did not differ significantly between the ages of cut. Additionally, according to these authors, the higher ash content observed in elephant grass was attributed to the high application of nitrogen fertilizer (400 kg N ha-1 year $\left.^{-1}\right)$.

\section{Conclusion}

The LAI, the productive characteristics and chemical-bromatological qualities of elephant grass are influenced by decrease cutoff frequency. The use of grass at 60 days implies an optimal point of production and quality.

\section{References}

ASSOCIATION OF ANALYTICAL CHEMISTS - AOAC. Official Methods of Analysis. $17^{\text {th }}$ ed. Gaithersburg: AOAC, 2003. p. 1094. 
CARVALHO, C. A. B.; ROSSIELlO, R. O. P.; PACIULLO, D. S. C.; SBRISSIA, A. F.; DERESZ, F. Classes de perfilhos na composição do índice de área foliar em pastos de capim-elefante. Pesquisa Agropecuária Brasileira, Brasília, v. 42, n. 4, p. 557-563, 2007. DOI: 10.1590/S0100-204X2007000400014

CARVALHO, D. M. G.; CABRAL, L. S.; ZERVOUDAKIS, J. T. Suplementos para ovinos mantidos em pastos de capim-marandu. Pesquisa Agropecuária Brasileira, Brasília, v. 46, n. 2, p.196-204, 2011. DOI: 10.1590/S0100-204X2011000200012

CHAVES, C. S. Produtividade de massa seca, morfologia e valor nutritivo de genótipos de capim-elefante sob estratégias de lotação intermitente. 2011. (Dissertação de Mestrado em Zootecnia) - Universidade Federal dos Vales do Jequitinhonha e Mucuri, Teófilo Otoni.

COSTA, C. S.; RODRIGUES, R. C.; SANTOS, F. N. S.; ARAÚJO, R. A.; SOUSA, G. O. C.; LIMA, J. R. L.; NUNES, D. R.; RODRIGUES, M. M. Structural characteristics and chemical composition of andropogon grass pasture managed under different defoliation intensities and rest periods. Revista Brasileira de Saúde e Produção Animal, Salvador, v. 19, n. 2, 166-177, 2017. DOI: 10.1590/S1519-99402017000400001

COSTA, K. A. P.; OLIVEIRA, I. P.; FAQUIN, V.; NEVES, B. P.; RODRIGUES, C.; SAMPAIO, F. M. T. Intervalo de corte na produção de massa seca e composição químico-bromatológica da Brachiaria brizantha cv. MG5. Ciência e Agrotecnologia, Lavras, v. 31, n. 4, p. $1197-$ 1202, 2007. DOI: 10.1590/S1413-70542007000400037.

CRUZ, R. S.; SANTOS, A. C.; CASTRO, J. G. D.; ALEXANDRINO, E.; CARAÇA, D. C.; DINIZ, J. P. Produtividade do Capim-Cameroon estabelecida em duas classes de solos e submetido a doses crescentes de nitrogênio no norte tocantinense. Acta Scientiarum. Animal Science, Maringá, v. 32, n. 1, p. 393-399, 2010. DOI: 10.4025 /actascianimsci.v32i4.6209

CUTRIM JUNIOR, J. A. A.; BEZERRA, A. P. A.; FARIAS, S. F.; AQUINO, R. M. S.; SOMBRA, W. A.; ANDRANDE, R. R.; CÂNDIDO, M. J.D. Morfofisiologia do Capim-tifton 85 manejado intensivamente sob corte. Acta Tecnológica, São Luís, v. 9, n. 1, 62-69. 2014.

FLORES, R. A.; URQUIAGA, S. S.; ALVES, B. J. R.; COLLIER, L. S.; MORAIS, R. F.; PRADO, R. de M. Adubação nitrogenada e idade de corte na produção de matéria seca do capim-elefante no Cerrado. Revista Brasileira de Engelharia Agrícola e Ambiental, Campina Grande, v. 16, n. 12, p.1282-1288, 2012. DOI: 10.1590/ S1415-43662012001200004.

FLORES, R. A.; URQUiAGA, S.; ALVES, B. J.
R.; COLliER, L. S.; ZANETTI, J. B.; PRADO, R. de $M$. Nitrogênio e idade de corte na qualidade da biomassa de capimelefante para fins agroenergéticos cultivado em Latossolo. Semina: Ciências Agrárias, Londrina, v. 34, n. 1, p. 127-136, 2013. DOI: 10.5433/1679-0359.2013v34n1p127

ITALiAnO, E. C.; PEREIRA, A. V.; LEDO, F. J. S. Comportamento produtivo de genótipos de capimelefante (Pennisetum purpureum) para corte na região meio-norte do Brasil. Revista Cientifica de Produção Animal, Recife, v. 8, n. 2, p. 47-55, 2006.

MAGALHÃES, J. A.; RODRIGUES, B. H. N.; CARNEIRO, M. S. S.; ANDRADE, A. C.; COSTA, N. L.; PINTO, M. S. C.; MOCHEL FILHO, W. J. Influência da adubação nitrogenada e idade de corte sobre os teores de proteína bruta e fibra em detergente neutro de três cultivares de capim-elefante. Revista Electrónica de Veterinaria, Andalucía, v. 10, n. 4, p. 1695-7504, 2009.

MARANHÃO. Governo do Estado. Gerência de Planejamento e Desenvolvimento Econômico. Universidade Estadual do Maranhão. Atlas do Maranhão. São Luís, Geplan, 2002. 39 p.

MARTINS-COSTA, R. H. A.; CABRAL, L. S.; BHERING, M.; ABREU, J. G.; ZERVOUDAKIS, J. T.; RODRIGUES, R. C.; OLIVEIRA, I. S. Valor nutritivo do capim-elefante obtido em diferentes idades de corte. Revista Brasileira de Saúde e Produção Animal, Salvador, v. 9, n. 3, p. 397-406, 2008.

MERTENS, D. R. Gravimetric determination of amylasetreated neutral detergent fiber in feeds with refluxing in beakers or crucibles: collaborative study. Journal AOAC International, v. 85, n. 6, p. 1217-1240, 2002.

MISTURA, C.; FONSECA, D. M.; MOREIRA, L.M.; FAGUNDES, J. F.; MORAIS, R. V.; QUEIROZ, A. C.; RIBEIRO JÚNIOR, J. I. Efeito da adubação nitrogenada e irrigação sobre a composição químico-bromatológica das lâminas foliares e da planta inteira de capim-elefante sob pastejo, Revista Brasileira de Zootecnia, Viçosa, v. 36 , n. 6 , p. 1707-1714, 2007. DOI: 10.1590/S151635982007000800002

PEDREIRA, B. C.; PEDREIRA, C. G. S.; SILVA, S. C. estrutura do dossel e acúmulo de forragem de Brachiaria brizantha cultivar Xaraés em resposta a estratégia de pastejo. Pesquisa Agropecuária Brasileira, Brasília v. 42, n. 2, p. 281-287, 2007. DOI: 10.1590/S0100204X2007000200018

PEREIRA, A. V.; AUAD, A. M.; LÉDO, F. J. S.; BARBOSA, S. Pennisetum Purpureum. In: FONSECA, D. M.; MARTUSCELLO, J.A. (Ed.). Plantas forrageiras. Viçosa: UFV, 2010. p. 197-219. 
RODRIGUES JÚNIOR, C. T.; CARNEIRO, M. S. S.; MAGALHÃES, J. A.; PEREIRA, E. S.; RODRIGUES, B. H. N.; COSTA, N. L.; PINTO, M. S. C.; ANDRADE, A. C.; PINTO, A. P.; FOGAÇA, F. H. S.; CASTRO, K. N. C. Produção e composição bromatológica do capim-Marandu em diferentes épocas de diferimento e utilização. Semina: Ciências Agrárias, Londrina, v. 36 , n. 3 , p. 2141-2154, 2015. Suplemento 1. DOI: 10.5433/1679-0359.2015v36n3Supl1p2141

SANCHÊS, S. S. C.; ARAÚJO, R. A.; RODRIGUES, R. C.; COSTA, C. S.; SANTOS, F. N. S.; RODRIGUES, I. S.; JESUS, A. P. R.; LIMA, N. M. Quantitative anatomy and in situ ruminal degradation parameters of elephant grass under different defoliation frequencies. Revista Brasileira de Saúde e Produção Animal, Salvador, v. 19, n. 2, 166-177, 2018. DOI: 10.1590/S151999402018000200003

SANCHÊS, S. S. C.; RODRIGUES, R. C.; ARAÚJO, R. A.; SANTOS, F. N. S.; SILVA, I. R.; FIGUEREDO, E. S.; CABRAL, L. S.; ARAÚJO, J. S.; COSTA, C. S. Anatomical characterization of elephant grass under different defoliation frequencies and levels of insertion on the tiller. Biological Rhythm Research, Londres, v. 50, n. 3, 1-10, 2019. DOI: 10.1080/09291016.2019.1583500

SANTOS, H. G.; JACOMINE, P. K. T.; ANJOS, L. H. C.; OLIVEIRA, V. A.; LUMBRERAS, J. F.; COELHO, M. R.; ALMEIDA, J. A.; CUNHA, T. J. F.; OLIVEIRA, J. B. Sistema brasileiro de classificação de solos. 3.ed. rev. e ampl. Brasília: Embrapa, 2013. 353 p.
SAS INSTITUTE. SAS user's guide: release; version 9.0. Cary: Statistical Analysis System Institute, 2002. $1028 \mathrm{p}$.

TEIXEIRA, A. M.; GONÇALVES, L. C.; VELASCO, F. O.; RIBEIRO JÚNIOR, G. O.; FARIA JÚNIOR, W. G.; CRUZ, D. S. G.; JAYME, D. G. Respirometria e emissão de metano por ovinos alimentados com capim-elefante cortado com diferentes idades. Bioscience Journal, Uberlândia, v. 31, n. 3, p. 841-849, 2015. DOI: 10.14393/ BJ-v31n3a2015-22577

VERAS, V. S.; OLIVEIRA, M. E.; LACERDA, M. S. B.; CARVAlho, T. B.; AlVES, A. A. Produção de biomassa e estrutura do pasto de capim andropogon em sistema silvipastoril e monocultura. Arquivo Brasileiro de Medicina Veterinária e Zootecnia, Belo horizonte, v. 61, n. 1 , p. $200-207,2010$. DOI: $10.1590 / \mathrm{S} 0102-$ 09352010000100027

VIANA, B. L.; MELLO, A. C. L.; LIRA, M. A.; DUBEUX JÚNIOR, J. C. B.; SANTOS, M. V. F.; CUNHA, M. V.; FERREIRA, G. D. G. Repetibilidade e respostas de características morfofisiológicas e produtivas de capim-elefante de porte baixo sob pastejo. Pesquisa Agropecuária Brasileira, Brasília, v. 44, n. 12, p. 17311738, 2009. DOI: 10.1590/S0100-204X2009001200024. 